\title{
POLITIČKA KOMUNIKACIJA KANDIDATA NA DRUŠTVENIM MREŽAMA NA HRVATSKIM PREDSJEDNIČKIM IZBORIMA 2019./2020.
}

\section{Gabriela Galić :: Domagoj Bebić}

IZVORNI ZNANSTVENI RAD / DOI: 10.20901/ms.12.23.5 / PRIMLJENO: 15.12.2020.

SAŽETAK Porast „politike usmjerene na kandidata“ utjecao je na promjenu u komunikacijskim strategijama političara koji se sve češće koriste tehnikama privatizacije politike za zbližavanje s biračima. Društvene mreže pokazale su se kao idealan kanal za "smekšavanje” njihovih imidža. Cilj je ovog rada istražiti jesu li se kandidati, i u kojoj mjeri, na hrvatskim predsjedničkim izborima 2019./2020. koristili društvenim mrežama za privatizaciju, odnosno personalizaciju politike. Metodom analize sadržaja utvrđeno je da su kandidati u svojim objavama u značajnoj mjeri koristili tehnike privatizacije politike kako bi se prikazali kao „jedni od nas". Pobjedu na izborima odnio je Zoran Milanović koji je u potpunosti vodio personaliziranu kampanju u kojoj je najčešće naglašavao svoj osebujni karakter i svoje privatne osobine.

\section{KLJUČNE RIJEČI}

HRVATSKA, PREDSJEDNIČKI IZBORI, FACEBOOK, PRIVATIZACIJA POLITIKE, PERSONALIZACIJA

Bilješka o autorima

Gabriela Galić :: gabriela.galic01@gmail.com

Domagoj Bebić :: Fakultet političkih znanosti, Sveučilište u Zagrebu :: domagoj@edemokracija.hr

Rad se temelji na istraživanju koje je Gabriela Galić provela za potrebe diplomskog rada koji je obranila na Sveučilištu u Zagrebu, na Fakultetu političkih znanosti 19. rujna 2019. godine. 


\section{UVOD}

Personalizacija politike proteklih je desetljeća postala jedan od važnijih fenomena u suvremenoj politici. $\mathrm{S}$ jedne strane, $\mathrm{u}$ tome su veliku ulogu odigrali mediji koji nastoje medijske sadržaje vezane uz politiku prikazati što zanimljivijima svojim publikama. Sve se više usmjeravaju na pojedine kandidate i čelnike stranaka, na njihove osobine i privatne živote, dok politički programi i konkretna rješenja padaju u drugi plan.

Međutim, s druge strane, političari često i sami u kampanjama naglašavaju svoj karakter i otkrivaju informacije iz privatnih života. Time se nastoje približiti biračima i prikazati sebe kao obične građane, odnosno kao "jedne od nas". Korištenje navedenih tehnika posebno je karakteristično za predsjedničke izbore na kojima se biraju pojedini kandidati. Svatko od kandidata traži način da se istakne i privuče birače pa tako kandidati u svojim kampanjama često posežu za tehnikama koje ih "humaniziraju“ i prikazuju njihovo "drugo“ lice s kojim se građani mogu lako poistovjetiti.

Društvene mreže, koje su namijenjene upravo povezivanju ljudi i dijeljenju osobnog sadržaja, čine idealan kanal za korištenje navedenih tehnika. Ipak, istraživanja koja su analizirala korištenje društvenih mreža u kampanjama na hrvatskim predsjedničkim izborima 2014./2015. pokazala su da kandidati nisu koristili društvene mreže za personalizaciju i stvaranje emotivne veze $s$ biračima, nego pretežito za dijeljenje informacija o kampanjama (Šimunjak i sur., 2017). Pet godina poslije, uslijedili su novi predsjednički izbori na kojima su, čini se, korištene i drugačije komunikacijske strategije. Ovaj rad nastojat će ponuditi odgovor na pitanje jesu li kandidati na hrvatskim predsjedničkim izborima 2019./2020. prepoznali potencijal društvenih mreža i koristili ih za privatizaciju, odnosno personalizaciju politike.

Uzimajući u obzir poruke koje su kandidati slali za vrijeme svojih kampanja i objave koje su u predizbornom razdoblju dijelili na svojim privatnim Facebook profilima, početna teza rada je da su predsjednički kandidati na Facebooku u vrijeme svojih kampanja u značajnoj mjeri koristili tehnike privatizacije politike s ciljem „humaniziranja“ svog imidža i približavanja građanima.

\section{PERSONALIZACIJA POLITIKE}

\section{Modernizacija i slabljenje utjecaja političkih stranaka}

Lipset i Rokkan 1967. godine iznijeli su tezu da su ideološke i stranačke podjele u društvu zapravo proizašle iz društvenih rascjepa koji su postojali unutar nacija (Lipset i Rokkan, 1967). Ti su rascjepi, objašnjava Grbeša, „ukorijenjeni u razlikama između konkurentskih društvenih skupina - poput klase ili religijskih skupina - i odražavaju dugotrajne društvene i ekonomske podjele, što pruža temelje za potencijalni politički sukob“ (Grbeša, 2008, str. 20). 
Referirajući se na Lipseta i Rokkana, Dalton navodi kako su društveni rascjepi „kroz povijest oblikovali sadržaj političkog i izbornog diskursa u zapadnim demokracijama, te stoga i stranačku opredijeljenost i izbore birača" (Dalton, 2003, str. 319). Međutim, proces modernizacije sa sobom je donio značajne promjene u društvenom i političkom okruženju. Društvo tada postaje sve složenije, što je rezultiralo nizom „radikalnih društvenih promjena, koje uključuju, posebice, promjene u obliku i praksama demokratske vladavine" (Swanson i Macini, 1996, str. 7).

Dolazi do porasta razine obrazovanja građana, razvoja masovnih medija, a samim time i veće dostupnosti informacija. Birači postaju osvješteniji, razvijaju svoje političke vještine te kao rezultat toga više i propitkuju odluke koje stranke i kandidati donose, ili se pak odlučuju za nestranački oblik političkog djelovanja (Dalton, 2000, str. 11).

Slabljenjem društvenih rascjepa, mijenjaju se i temelji ideoloških podjela u brojnim zapadnim demokracijama. „Publike u ovim društvima proširile su svoje interese na neekonomska pitanja koja se tiču kvalitete života, koja predstavljaju novu postmaterijalnu agendu" (Dalton, 2003, str. 320). Javljaju se, primjerice, različiti pokreti žena koje zahtijevaju jednaka prava kao i muškarci, pokreti koji se zalažu za zaštitu manjina u društvu ili pak za zaštitu okoliša. Na agendu se stavljaju nove teme koje se više ne tiču klasnih podjela i koje su „stvorile nove baze za stranačke konflikte“ (Dalton, 2003, str. 320). Istodobno raste i broj birača koji svoju odluku o tome kome će dati svoj glas donose na temelju odnosa kandidata prema specifičnim problemima i pitanjima.

S modernizacijom dolazi i do svojevrsne promjene životnog stila, čime se otvara prostor sve većoj individualizaciji. Grbeša navodi (2008, str. 22) kako su članstva u tradicionalnim društvenim institucijama, kao što su stranke ili sindikati, zamijenila članstva u pokretima koji se bave specifičnim problemima, poput pokreta za zaštitu okoliša. "U takvom promijenjenom okruženju, glasovanje na izborima u sve većoj mjeri postaje izraz individualnog izbora, prije nego izraz pripadnosti grupi" (Grbeša, 2008, str. 22). Swanson i Macini iznose sličnu tezu te pišu kako glasovi birača sve više ovise o njihovoj vezi s pojedinačnim kandidatom, dok tradicionalne veze između birača i političkih stranaka, kao rezultat toga, slabe (1996, str. 14).

Upravo je slabljenje tradicionalnih veza jedan od dvaju faktora koji su prema Van Aelst i sur. (2011, str. 204) utjecali na porast 'politike usmjerene na kandidata'. Drugi faktor koji navode odnosi se na promjene u medijskom okruženju, s posebnim naglaskom na ulogu televizije u političkoj komunikaciji. Razvoj televizije „fundamentalno je promijenio prirodu političke komunikacije“, a jedna od najvažnijih promjena je ta što je televizija „nametnula nova pravila izvještavanja i proizvela novi stil prezentacije koji je skloniji vidljivim osobnostima više nego kompleksnim problemima i institucijama" (Grbeša, 2008, str. 31). Budući da se političari zbog novonastalih promjena u društvenom i političkom okruženju više nisu mogli s jednakom sigurnošću osloniti na birače koji su tradicionalno glasovali za njih ili njihovu političku stranku, oni počinju mijenjati svoje komunikacijske strategije i prila- 
gođavati ih novim okolnostima. Istodobno se sve više počinje govoriti i o "personalizaciji politike", koja postaje jedan od ključnih pojmova u suvremenoj politici.

\section{Koncept personalizacije politike}

Proteklih desetljeća personalizacija politike postala je popularna tema brojnih radova iz područja političkih znanosti. Međutim, usprkos velikom interesu za taj fenomen, u znanstvenoj zajednici još uvijek ne postoji jedinstvena definicija "personalizacije". Grbeša nudi definiciju tog pojma u širem smislu:

Personalizacija se odnosi na povećani interes medija za kandidate i čelnike stranaka, kao i porast njihovog značaja i vidljivosti unutar stranačke strukture i za vrijeme izbornih kampanja, što se prvenstveno razvilo kao posljedica propasti politike cijepanja, pojave novih medijskih tehnologija i brzog širenja medijskog tržišta. (Grbeša, 2008, str. 12)

Većina autora koji se bave personalizacijom slažu se da je riječ o fenomenu koji je potrebno promatrati u više dimenzija. Van Aelst i sur. (2011) tako pišu o jednoj od dimenzija koju nazivaju „individualizacija“. Ona se odnosi na prebacivanje fokusa s političkih stranaka i tema „na pojedine političare kao središnje aktere u političkoj areni, uključujući njihove ideje, kapacitete i politike" (Van Aelst i sur., 2011, str. 204). Karvonen (2009, str. 4) tu dimenziju definira kao „pojavu kada pojedini politički akteri postaju sve istaknutiji, na štetu stranaka i kolektivnih identiteta".

Uz pojam individualizacije, u parlamentarnim sustavima često se veže i još konkretniji koncept „prezidencijalizacije“ (Mughan, 2000). Taj se pojam odnosi na pojavu u kojoj „premijeri u parlamentarnim sustavima imaju sve sličniji položaj predsjednicima u predsjedničkim sustavima s obzirom na njihovu važnost i vidljivost u političkoj komunikaciji, ali i politici generalno" (Šimunjak, 2012, str. 35-36). Međutim, budući da su tema ovog rada predsjednički izbori, ovaj se rad neće baviti tom dimenzijom, već će fokus biti na dimenziji personalizacije poznatoj pod nazivom "privatizacija političara" (Holtz-Bacha, 2004), odnosno "politizacija privatnosti" (Langer, 2010).

Šimunjak (2012, str. 36) taj pojam definira kao "proces kojim se u političkoj komunikaciji fokus s političkih persona političara premješta na njihove privatne persone". Drugim riječima, sve veći naglasak stavlja se na političare kao "obične ljude" te na njihove privatne živote i osobine.

Važno je istaknuti kako se tim tehnikama koriste i mediji i političari. Mediji, usmjereni na profit i stjecanje što brojnije publike, medijske izvještaje o političkim zbivanjima pokušavaju učiniti što atraktivnijim pa tako nerijetko u izvještajima o političarima ističu detalje i priče iz njihovih privatnih života. S druge strane, političari te tehnike koriste kako bi se približili biračima te im pokazali da su i oni zapravo samo „obični građani“. 


\section{PRIVATIZACIJA POLITIČARA KAO STRATEGIJA KANDIDATA}

\section{Koncept privatizacije političara}

Prema Van Aelst i sur. (2011, str. 206), privatizacija političara odnosi se na „porast važnosti političara kao 'obične' osobe“. Drugim riječima, fokus se premješta na njih kao privatne pojedince, a "političar više nije predstavljen samo kao kreator politike ili kao glasnogovornik, već kao predani roditelj ili strastveni ljubitelj glazbe" (Van Aelst i sur., 2011, str. 206).

Langer (2006, str. 51) politizaciju privatne persone definira kao "vidljivost koja je data osobnoj sferi političkih figura u procesu stvaranja njihovih javnih osoba i koja ih prikazuje kao one koji otkrivaju, namjerno ili nenamjerno, svoje 'autentične' sebe".

Govoreći o privatizaciji političara, za početak je potrebno definirati što to podrazumijeva "privatni život" političara. Van Aelst i sur. (2011, str. 213) privatni život definiraju kao domenu "izvan političke arene, gdje postupci i riječi političara nisu eksplicitno povezani s njegovom ili njezinom javnom ulogom". Upravo se ti elementi sve češće koriste u izbornim kampanjama za "konstruiranje prikladne autobiografije za potencijalnog političara, što pruža uvid u osobu iza imidža“ (Stanyer i Wring, 2004, str. 3).

Više je razloga zašto političari ističu informacije iz svojih privatnih života. Prema Šimunjak (2012, str. 36), komercijalni mediji, kojima je uvelike stalo do profita, vode se logikom da publici ponude ono što ih zanima. Drugim riječima, ako publiku ne zanima politika, onda će politike na televiziji biti manje ili će ju se prikazati u nekoj "lakšoj" formi. Političari se stoga prilagođavaju interesima medija i publika te pristaju otkrivati zanimljive detalje iz svog privatnog života.

Drugi je razlog taj što političari žele osvojiti i drugačiju publiku, odnosno žele pridobiti glasove nezainteresiranih i mladih birača. Svjesni su da takve birače dobar dio pitanja koja se tiču ideologije i svjetonazora ne interesira pa do njih pokušavaju doprijeti otkrivanjem zgoda i crtica iz svoga privatnog života, s kojima se lako poistovjetiti. Njima se nastoje svidjeti ponajprije kao osobe, a zatim i kao političari.

Šimunjak (2012, str. 37) kao još jedan od razloga navodi i potrebu za diferencijacijom u društvima koja nisu ideološki i vrijednosno podijeljena. U okruženju u kojemu slabe tradicionalne veze između birača i stranaka, političari moraju naći nove načine da se razlikuju od konkurencije, odnosno da biračima pokažu zašto su baš oni pravi izbor za njih.

\section{Funkcije privatizacije političara}

Holtz-Bacha definira (2004, str. 49) četiri funkcije privatizacije političara: humanizacija, pojednostavljivanje i distrakcija, emocionalizacija te dosezanje celebrity-statusa.

Humanizacija je, prema Holtz Bachi (2004, str. 49), strategija upravljanja imidžom, koju političari koriste kako bi se glasačima prikazali kao obični građani, odnosno kao "jedni od nas". Slikajući se sa svojom obitelji, otkrivanjem svojih hobija i druženjem s građanima, 
političari nastoje prikazati svoju privatnu stranu kako bi se glasači mogli lakše poistovjetiti s njima. Krajnji je cilj korištenja tehnika humanizacije u strategijama političara, objašnjava Holtz-Bacha (2004, str. 49), da pokažu razumijevanje za birače, kako bi se maknuli od ideje da oni ne mare ili ne razumiju "obične ljude" i njihove probleme.

Sljedeća funkcija privatizacije je pojednostavljivanje. Holtz-Bacha navodi kako se ona odnosi na "čest način nošenja s kompleksnim političkim problemima koje je teško priopćiti biračima" (Holtz-Bacha, 2004, str. 49). Drugim riječima, političari utjelovljuju građanima ponekad teško shvatljive političke programe i ideje. Pored pojednostavljivanja, političari se također služe privatizacijom politike za distrakciju, kako bi skrenuli fokus s nekih neugodnih tema ili pitanja.

Emocionalizacija se koristi kako bi se kod birača izazvalo suosjećanje te kako bi se s njima stvorila emotivna veza. Holtz-Bacha ističe (2004, str. 49) kako je to posljedica slabljenja stranačke identifikacije, budući da sociodemografske karakteristike sve slabije mogu opisati glasačko ponašanje birača. Političari s glasačima dijele svoja osobna iskustva i emocije, kako bi izazvali empatiju te se tako dublje povezali s njima.

Posljednja funkcija odnosi se na dosezanje celebrity-statusa, odnosno na "ideju da političari žele i imaju potencijal za stjecanje celebrity-statusa koji je inače rezerviran za zvijezde iz šoubiznisa, koji bi ih možda mogao učiniti privlačnijima širim publikama" (Grbeša, 2008, str. 36). Povezivanje s popularnom kulturom dobra je prilika političarima da dopru do nezainteresiranog dijela birača te da sebe prikažu u drugačijem svjetlu.

\section{Društvene mreže i upravljanje političkim imidžom}

Novi mediji i društvene mreže proteklo su desetljeće postale važne platforme u političkim kampanjama. Toj tezi u prilog ide činjenica kako je u Hrvatskoj u lipnju 2020. godine, prema podatcima Internet World Statsa, 92,3 posto građana koristilo internet. Odnosno, u brojkama ukupno 3,787,838 hrvatskih građana, od kojih njih više od pola, točnije 2,077,000, koristi društvenu mrežu Facebook (Internetworldstats.com, 2020). Iz toga proizlazi da se na Facebooku nalazi polovica hrvatskoga stanovništva, a samim time i velik broj birača, što političarima predstavlja novo mjesto za privlačenje potencijalnih birača različitih društvenih i dobnih skupina.

Istraživanja hrvatskih predsjedničkih izbora 2014./2015. pokazala su da su kandidati u velikoj mjeri koristili društvene mreže u svojim kampanjama, ali ne i za personalizaciju i zbližavanje s biračima (Šimunjak i sur., 2017; Sinčić Ćorić i sur., 2017).

Govoreći o učestalosti korištenja društvenih mreža tijekom kampanje, Šimunjak i sur. zaključuju (2017, str. 548) kako je "značajno više izjava objavljeno na društvenim mrežama nego u dnevnim novinama". Zanimljiv je podatak da je svih četvero kandidata na spomenutim izborima značajno više naglašavalo svoje vrline i kvalitete u posredovanim izjavama nego na društvenim mrežama (Šimunjak i sur., 2017, str. 549). Najčešće su promovirali istu svoju vrlinu, odnosno svoju sposobnost za obnašanje dužnosti predsjednika Republike, što 
pokazuje da "nisu prepoznali ili nisu bili voljni razlikovati se od konkurencije svojim jedinstvenim vrlinama i vještinama, i posljedično, stvoriti prepoznatljiv brend" (Šimunjak i sur., 2017, str. 549). Također, nitko od kandidata nije želio iznositi detalje iz svojih privatnih života.

Analizirajući dosezanje, uključivanje i zbližavanje s biračima na istim predsjedničkim izborima, Sinčić Ćorić i sur. zaključuju (2017, str. 68) kako su u izjavama svih kandidata najčešće teme bile one koje su vezane za kampanju, a uvida u njihov privatni život gotovo da nije ni bilo.

Navedeni podatci upućuju na to da su kandidati na hrvatskim predsjedničkim izborima 2014./2015. propustili iskoristiti potencijal društvenih mreža za zbližavanje s biračima te da su ih više koristili za slanje političkih poruka i dijeljenje informacija o samim kampanjama. Na spomenutim predsjedničkim izborima pobjedu u drugom krugu protiv aktualnog predsjednika Ive Josipovića odnijela je kandidatkinja Hrvatske demokratske zajednice, Kolinda-Grabar Kitarović. Pet godina kasnije uslijedili su novi predsjednički izbori, a s njima i nove političke kampanje s različitim komunikacijskim strategijama.

\section{PREDSJEDNIČKI IZBORI 2019./2020.}

\section{Kontekst predsjedničkih izbora 2019./2020.}

Na posljednjim hrvatskim predsjedničkim izborima 2019./2020. bilo je čak 11 službenih kandidata. Već na samom početku kampanje, ankete i brojni politički analitičari prognozirali su kako je najvjerojatnije da će u drugi krug ući tada još uvijek aktualna predsjednica Kolinda Grabar-Kitarović i Zoran Milanović, a nešto slabiji izgledi za ulazak u drugi krug davali su se i Miroslavu Škori. Primjerice, u istraživanju agencije IPSOS koje je početkom prosinca 2019. objavio Dnevnik Nove TV, Grabar-Kitarović se prognoziralo 27,4 posto glasova birača, Milanoviću 24 posto, a Škori 23 posto. Ostalim kandidatima nisu se davale šanse za prolazak u drugi krug (Bago, 2019a). Ovo istraživanje obuhvatit će objave vodećih troje kandidata kojima su se davale najveće šanse za ulazak u drugi krug. U sljedećem dijelu rada svatko od njih bit će pojedinačno predstavljen.

\section{Žena iz naroda}

„Ja sam vaša i bit ću vaša predsjednica“ - tim je riječima u prosincu 2014. godine u rodnim Dražicama na Grobniku Grabar-Kitarović započela svoju službenu kampanju za predsjedničke izbore. Predstavljajući se na svom prvom skupu kao žena "skromnih, težačkih korijena“, uz poruku "ja sam Kolinda, žena iz naroda“ (Opačak Klobučar, 2014), bilo je jasno kako će Grabar-Kitarović voditi kampanju u kojoj će se služiti populizmom kako bi osvojila naklonost hrvatskih građana.

U vrijeme kada se Grabar-Kitarović kandidirala za svoje prve predsjedničke izbore, Zoran Milanović obnašao je dužnost predsjednika Vlade. Upravo su napadi na Milanovićevu Vladu obilježili njezinu predsjedničku kampanju. Primjerice, na završnom skupu održanom u zagrebačkom Domu sportova, Grabar-Kitarović tadašnju je Vladu nazvala 
„nesposobnom", „bezidejnom“ i „,bešćutnom", Ive Josipovića jer oni su samo dva lica iste devalvirane kovanice“ (Opačak Klobučar, 2014).

Raos objašnjava (2015, str. 37) kako „sraz Josipovića i Grabar-Kitarović, dakako, nije bio samo sraz dvaju pretendenata na mjesto predsjednika odnosno predsjednice, već i sučeljavanje Kukuriku koalicije i HDZ-a“. U tijesnoj pobjedi, s 50,74 posto osvojenih glasova birača, Grabar Kitarović odnijela je pobjedu u drugom krugu, dok je SDP-ov kandidat Ivo Josipović osvojio 49,26 posto glasova (Državno izborno povjerenstvo Republike Hrvatske, 2014). Time je postala prva žena na funkciji predsjednice Republike.

O utjecaju Grabar-Kitarović u vrijeme kada je obnašala funkciju predsjednice govori činjenica da ju je ugledni američki časopis Forbes uvrstio na listu najmoćnijih žena svijeta 2017. godine i to na 39. mjestu, dok se godinu dana kasnije na istoj listi našla na nešto nižem 47. Mjestu (Forbes, 2019). Njezin petogodišnji mandat obilježila su brojna putovanja - kako u Hrvatskoj, tako i u inozemstvu - koja je kasnije često isticala u kampanji za drugi predsjednički mandat, navodeći u svojim govorima i na društvenim mrežama kako je obišla "svaki kutak Domovine“ (Dnevnik.hr, 2019a). Obilazeći Hrvatsku nije se ustručavala zapjevati, zaplesati baranjsko kolo, kuhati, ribariti i družiti se s građanima. Na društvenim mrežam dijelila je sadržaj na kojem je prikazana u neformalnom, svakodnevnom okruženju. Primjerice, na Facebooku je objavljivala fotografije na kojima pozira s građanima, sa svojim psom, kako kupuje na tržnici, sudjeluje u svetoj misi i slično.

Prema podatcima Državnog izbornog povjerenstva, u prvom krugu predsjedničkih izbora 2019./2020. pobjedu je odnio Milanović, s 29,55 posto podrške birača, dok je Grabar-Kitarović ostvarila rezultat od 26,65 posto (Državno izborno povjerenstvo Republike Hrvatske, 2020). Iznenađenje izbora svakako je bio Škoro, koji je ostvario značajno veći rezultat nego što su mu predizborne ankete davale uoči samih izbora. Dva dana prije predsjedničkih izbora Dnevnik Nove TV objavio je rezultate posljednje ankete prije izbora, prema kojoj je Škoro trebao osvojiti 18 posto glasova birača (Bago, 2019b). Međutim, osvojio je 24,45 posto glasova, odnosno u brojkama samo 41.924 glasa manje od Grabar-Kitarović. Svoje birače pozvao je da u drugome krugu ponište listić i time Grabar-Kitarović uskratio dio potencijalnih glasova svojih birača.

U drugom krugu s 1.034.170 glasova pobjedu je odnio Milanović. Imao je 104.463 glasova više od protukandidatkinje (Državno izborno povjerenstvo Republike Hrvatske, 2020). Uspoređujući političku retoriku kandidata koji su se borili u drugom krugu, profesor s Fakulteta političkih znanosti u Zagrebu Dražen Lalić u razgovoru za N1 dao je zanimljivu usporedbu. „Milanovićeva je retorika moćna, u usporedbi s retorikom Kolinde Grabar- Kitarović njegova je retorika kao moćni Mercedes, a njena kao polovni Golf" (Hr. n1info.com, 2019).

Na predsjedničkim izborima 2019./2020. pobjedu je odnio kandidat koji je uživao podršku u tom trenutku slabije stranke. Prema istraživanju agencije IPSOS objavljenom u

\footnotetext{
${ }^{1}$ Puljić-Šego, I. (2015, 7. siječnja). Euforičan skup HDZ-a u Domu sportova: 'Dosta je bilo ZoranaMilanovića i Ive Josipovića'. Večernji.hr. Preuzeto 15.7.2020., s https://www.vecernji.hr/vijesti/euforican-skup-hdz-a-u-domu-sportova-dosta-je-bilozorana-milanovica-i-ive-josipovica-982956
} 
Dnevniku Nove TV, Hrvatska demokratska zajednica potkraj studenog 2019. uživala je potporu 27,1 posto građana, dok je Socijaldemokratska partija imala 20,7 posto (Dnevnik.hr, 2019b). Iz toga proizlazi zaključak da na ovim predsjedničkim izborima presudnu ulogu nije imala stranačka potpora. Grabar-Kitarović uvelike je i sama utjecala na svoj poraz, a Hrvatska je dobila „predsjednika s karakterom”.

\section{Predsjednik s karakterom}

"Nisam predsjednik i nikada neću biti predsjednik Republike Hrvatske", poručio je to u travnju 2014. godine tadašnji predsjednik Vlade i šef Socijaldemokratske partije Milanović (Mahmutović, 2019). Od tada se mnogo toga dogodilo u njegovoj političkoj karijeri - od poraza na parlamentarnim izborima, napuštanja Sabora i okretanja privatnom biznisu u konzultantskoj tvrtki - do pobjede na predsjedničkim izborima.

Bivši djelatnik Ministarstva vanjskih poslova i diplomat u svojoj karijeri ostvario je strelovit uspjeh. Početkom 2000-ih počeo se aktivno baviti politikom, a nakon smrti tadašnjeg predsjednika SDP-a Ivice Račana u travnju 2007. godine, iste godine u studenome Milanović pobjeđuje na izvanrednim unutarstranačkim izborima. Nakon četiri godine provedene u oporbi, u prosincu 2011. godine uslijedili su parlamentarni izbori, a veliki pobjednik tih izbora bila je Kukuriku koalicija predvođena SDP-om s 80 osvojenih mandata (Državno izborno povjerenstvo Republike Hrvatske, 2011).

U svome se mandatu Milanović nije ustručavao upuštati u žustre rasprave s političkim neistomišljenicima, a upravo se zbog svog osebujnog stila komunikacije često našao na meti kritika. Grbeša-Zenzerović navodi neke od najistaknutijih primjera koji ilustriraju komunikacijski stil bivšeg premijera:

Tu sarkastično-podcjenjivačku komunikaciju hrvatski premijer demonstrirao je na različitim publikama: neposlušnim ministrima ('Samo kaj mi nije palo 20 kila smeća na nogu kad sam čuo izjavu ministrice', komentar na Mirelu Holy dok je bila ministrica zaštite okoliša i prirode); političkim protivnicima ('Ruža Tomašić gora je od elementarne nepogode. Građani su u mnogim zemljama birali svašta.'); prebjezima ('Lesi se vraća kući', komentar na djelatnicu Ministarstva rada koja je prešla u sindikat zdravstva); novinarima ('Mislim da je kriv pokojni predsjednik Kennedy', odgovor na pitanje novinara je li Vlada odgovorna za provođenje referenduma inicijative U ime obitelji); i građanima ('Stručnjaci za finski rat iz Špičkovine ili Vukovine nam objašnjavaju koliko je bilo mrtvih kao da su ih oni osobno prebrojavali', antologijski komentar na profesora povijesti kojeg su novinari zamolili da iznese povijesne činjenice o građanskom ratu u Finskoj, a na koje se Milanović ranije netočno referirao). Takav komunikacijski obrazac sasvim je u suprotnosti s popularnim svjetskim trendovima koji nastoje političare približiti 'običnim građanima'. (Grbeša-Zenzerović, 2014, str. 42)

Milanović je gradio imidž iskrenog političara koji govori ono što mu je na umu, bez uljepšavanja i dodvoravanja drugima. Međutim, pritom je „zastranio u ekstreman komunikacijski obrazac koji je teško opisati raspoloživim stručnim pojmovima“" (Grbeša-Zenzerović, 2014, str. 42). Ulazeći u zadnju godinu mandata, popularnost njegove Vlade sve je 
bila manja. Grbeša-Zenzerović navodi podatke ankete koje je u studenom 2014. provela agencija Ipsos Plus koji to ilustriraju: „Prema rezultatima ankete koju je provela agencija Ipsos Puls, prosječna ocjena Vlade u studenom 2014. iznosila je 2,1. Vladinoj politici u istome mjesecu protivilo se 77 posto ispitanika, dok je njih 85 posto smatralo da Hrvatska ide u pogrešnom smjeru“ (Grbeša-Zenzerović, 2014, str. 39).

Na loš imidž Milanovićeve Vlade utjecalo je više čimbenika, a kao jedan od važnijih Grbeša-Zenzerović ističe upravo Milanovićev stil komunikacije (2014, str. 43). Pad popularnosti SDP-a odrazio se i na rezultat predsjedničkih izbora 2014./2015. kada je njihov kandidat Josipović izgubio od HDZ-ove kandidatkinje Grabar-Kitarović. Nedugo nakon predsjedničkih izbora, uslijedilo poraz SDP-a na parlamentarnim izborima u studenom 2015., a potom i na prijevremenim parlamentarnim izborima u srpnju 2016. godine. Novi katastrofalni poraz SDP-a rezultirao je time da je Zoran Milanović na izvanrednoj konferenciji objavio kako se neće više kandidirati za funkciju predsjednika SDP-a. Nedugo nakon toga objavio je i da se povlači iz aktivne politike.

U lipnju 2019. na svom Facebook profilu objavio je fotografiju s natpisom „predsjednik s karakterom" te time potvrdio nagađanja da će se kandidirati na nadolazećim predsjedničkim izborima. Slogan njegove kampanje najavio je da će Milanović voditi personaliziranu kampanju u kojoj će u fokusu biti njegov karakter - koji mu je u vrijeme njegove Vlade istodobno bio najveća kvaliteta, ali i uteg. U svom uvodnom obraćanju građanima dao je naslutiti da će ga u ovoj kampanji imati priliku vidjeti u nešto drugačijem svjetlu - kao smirenijeg, manje konfliktnog i staloženijeg političara.

Tijekom kampanje u svojim objavama na društvenim mrežama naglašavao je svoj karakter, vrline i dosadašnja postignuća. Pozivao je građane za da glasaju za promjenu, odnosno za modernu i „normalnu“ Hrvatsku. Napadao je protukandidatkinju Grabar-Kitarović i HDZ, a tek u pokojoj objavi osvrnuo se i na protukandidata Miroslava Škoru, kojeg je nešto manje od 42 tisuće glasova birača dijelilo od drugog kruga predsjedničkih izbora.

\section{Narodni predsjednik}

U petominutnom videu na svom Facebook profilu Miroslav Škoro u lipnju 2019. objavio je svoju kandidaturu za predsjednika Republike. „Želim biti narodni predsjednik i samo ću vama polagati račune“, poručio je hrvatskim građanima. Pjevač, skladatelj, producent i poduzetnik pretežito konzervativnih i tradicionalnih stajališta nakon duge pauze u svijetu politike odlučio se kandidirati za funkciju predsjednika države. U svom uvodnom obraćanju na Facebooku istaknuo je da Hrvatska treba predsjednika koji će biti oruđe naroda i koji će se boriti protiv političkih elita i vratiti vlast narodu. To obraćanje sadržavalo je sve značajke populizma. Berto Šalaj navodi koje su temeljne ideje na kojima počiva populizam:

Središnja je ideja populizma da je društvo podijeljeno u dvije homogene i antagonističke skupine: pošteni narod i korumpiranu elitu. Tako Meny i Surel (2002) naglašavaju da populizam prožima ideja dobroga, poštenog i jednostavnog naroda kojega su prevarile i izmanipulirale korumpirane, nekompetentne i međusobno umrežene elite. Populisti tvrde da društvo i politiku treba korjenito promijeniti kako bi se ukinula do- 
minacija elita te obnovile zamisao i praksa politike kao izraza volje naroda. (Šalaj, 2012, str. 55)

Upravo se tim tehnikama u svojoj kampanji služio Škoro - kritizirao je protukandidate Grabar-Kitarović i Milanovića, na koje se referirao kao na pripadnike elite, ističući da su oni „dva lica istog korumpiranog klijentelističkog sustava“.

Henjak objašnjava (2019, str. 420) kako se posljednji predsjednički izbori „uklapaju u trend slabljenja blokova i povećanja broja birača koji su izvan blokova i koji glasaju za stranke i kandidate koji traže promjenu prevladavajućeg modela politike i zamjenu političkih elita“. Škoro se "uspio nametnuti kao najvjerodostojniji nositelj kritike prevladavajućeg modela politike“ i uspio je „okupiti podršku koja je znatno šira od razočaranih birača HDZ-a i desnice, i koja uključuje velik broj protestnih birača koji nemaju jasan stranački ili blokovski identitet" (Henjak, 2019, str. 421).

U svojoj kampanji obraćao se široj publici i svima onima nezadovoljnima trenutnom vlašću. Na društvenim mrežama dijelio je fotografije na kojima je sebe nastojao prikazati kao ozbiljnog političara, ali i kao „predsjednika iz naroda“. Usprkos tome što nije ušao u drugi krug, na ovim se predsjedničkim izborima pozicionirao kao čvrsta treća opcija na hrvatskoj političkoj sceni, što je potvrdio i na parlamentarnim izborima u srpnju 2020., na kojima je sa svojim Domovinskim pokretom osvojio 16 mandata u Hrvatskom saboru.

\section{METODOLOGIJA I ISTRAŽIVAČKI NACRT}

Kao što je prethodno u radu objašnjeno, privatizacija političara može se promatrati na dvije razine: kako mediji ističu privatne živote i karakteristike kandidata te kako to rade sami kandidati. Ovaj rad fokusirat će se isključivo na drugu razinu i nastojat će ponuditi odgovor na sljedeće istraživačko pitanje: jesu li i u kojoj mjeri kandidati na hrvatskim predsjedničkim izborima 2019./2020. koristili društvene mreže za privatizaciju, odnosno personalizaciju politike?

Kako bi odgovorili na postavljeno pitanje, metodom analize sadržaja autori su istražili Facebook objave troje predsjedničkih kandidata. Jedinica analize istraživanja je jedna objava na Facebooku. Analiza obuhvaća sve objave objavljene u prvom krugu predsjedničkih izbora između 1. i 22. prosinca 2019. na privatnim Facebook profilima troje kandidata koji su tijekom studenoga i prosinca uživali najviši stupanj potpore birača, odnosno na profilima Kolinde Grabar-Kitarović, Zorana Milanovića i Miroslava Škore. Istraživanje tako uključuje 243 objave.

Prilikom kreiranja analitičke matrice autori su se oslonili na istraživanje Grbeše (2008) na temu personalizacije politike na hrvatskim parlamentarnim izborima 2003. i 2007. godine. Matrica uključuje deset pitanja. Prvo pitanje odnosi se na format objave na društvenim mrežama. Objava je kodirana kao tekst, fotografija, fotografija i tekst, galerija fotografija, galerija fotografija i tekst, video te video i tekst. 
Druga kategorija istražuje tko su glavni akteri u objavi, kako bi se utvrdilo u kojoj su mjeri sami kandidati bili u fokusu svojih objava, a u kojoj su mjeri glavni akteri objava bili predstavnici stranke koja ih podupire, građani, predstavnici određenih interesnih skupina, slavne osobe, članovi obitelji ili drugi.

Treće pitanje vezano je uz dominantnu strategiju objave. Pored napada na protivnike, u odgovorima su ponuđene i strategije isticanja domoljublja, podržavanja tradicionalnih vrijednosti, zajedništva i/ili ideologije, zatim isticanje kandidata, njegova/njezina karaktera, vještina ili vrlina kao glavni razlog glasovanja za tog kandidata/kandidatkinju, isticanje dosadašnjih postignuća, poziv na promjene, isticanje optimizma za budućnost i davanje obećanja za budućnost, podrška slavnih osoba, humor ili ironija te ostalo.

Naposlijetku, zadnji set pitanja usmjeren je na korištenje tehnika privatizacije u objavama kandidata. Četvrto pitanje odnosi na to jesu li kandidati u objavi prikazani kao državnici, „jedni od nas", kao kombinacija toga dvoga ili nije moguće utvrditi.

Od petog do desetog pitanja nastoji se utvrditi postojanje nekih od elemenata privatizacije u objavama kandidata, kao što je prisutnost supruge ili supruga, poznatih osoba iz svijeta showbusinessa, sporta ili kulture te referiranje na religiju. Pored toga, analizira se je li kandidat prikazan u neformalnom, svakodnevnom okruženju, u interakciji s građanima te otkriva li informacije iz privatnog života (o svom podrijetlu, djetinjstvu, obitelji). Podudarnost kodera iznosi od $81 \%$ do $100 \%$, ovisno o kategoriji.

\section{PRIKAZ REZULTATA}

\section{Kolinda Grabar-Kitarović}

Kandidatkinja Kolinda Grabar-Kitarović u analiziranom razdoblju ukupno je objavila 78 objava, koje su pretežito bile u formatu fotografije i teksta $(28,10 \%)$ te galerija fotografija i teksta (24,36 \%). U Grafikonu 1. prikazano je koliko je koji format objave u analiziranom razdoblju bio zastupljen na njezinu Facebooku.

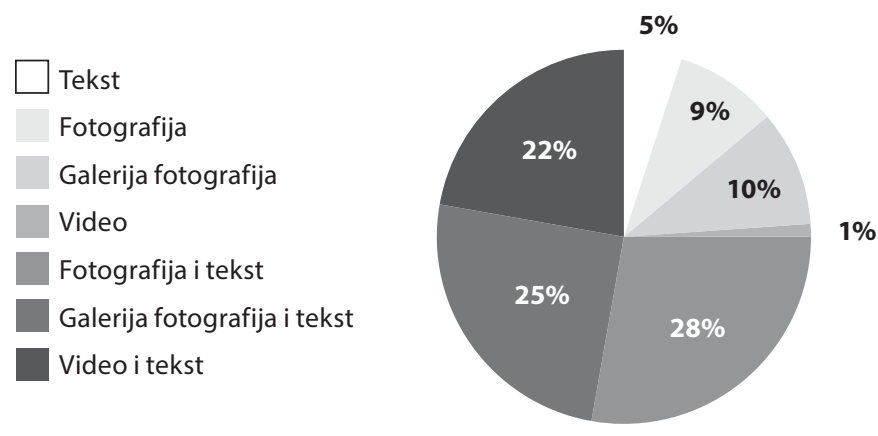


Glavni akteri u objavama Grabar-Kitarović navedeni su u Tablici 1. U najvećem broju objava Grabar-Kitarović glavni akter bila ona (74,36 \%), nakon čega slijedi kombinacija nje i predstavnika stranke (8,97 \%). Među predstavnicima stranke koji su je podržali i pojavljivali se u njezinim objavama jesu predsjednik HDZ-a Andrej Plenković, tadašnji glavni tajnik HDZ-a Gordan Jandroković, tadašnji ministar obrane Damir Krstičević, ministar branitelja Tomo Medved, vukovarski gradonačelnik Ivan Penava, župan Osječko-baranjske županije Ivan Anušić te župan Šibensko-kninske županije Goran Pauk. U 3,85 \% objava glavni akteri bili su Penava, Medved te Anušić.

Tablica 1. Glavni akter u objavama Kolinde Grabar-Kitarović

\begin{tabular}{ll} 
Glavni akter u objavama Kolinde Grabar-Kitarović & \\
Kandidatkinja & $74,36 \%$ \\
Predstavnik stranke & $3,85 \%$ \\
Građanin & $/$ \\
Predstavnik određene društvene ili interesne skupine & $2,56 \%$ \\
Slavna osoba & $/$ \\
Član obitelji & $/$ \\
Kandidatkinja + predstavnik stranke & $8,97 \%$ \\
Kandidatkinja + predstavnik stranke + član obitelji & $1,28 \%$ \\
Kandidatkinja + predstavnik stranke + slavna osoba & $3,85 \%$ \\
Nije moguće odrediti & $5,13 \%$ \\
UKUPNO & 100 \\
\hline
\end{tabular}

Grabar-Kitarović u svojoj se kampanji najviše oslanjala na strategiju isticanja domoljublja, podržavanja tradicionalnih vrijednosti, zajedništva i/ili ideologije (24,36 \%), što govori da je u svojoj kampanji kao jedan od glavnih ciljeva imala zadržavanje glasova desnoga biračkog tijela, za čiju se naklonost i Škoro borio. Pored toga, u objavama je često pozivala na promjene, isticala optimizam za budućnost, pobjednički entuzijazam i/ili davala obećanja za budućnost (17,95 \%). U 14,10\% objava dominantna strategija bila je isticanje sebe, svog karaktera, vještina ili dosadašnjih postignuća. Pretežito je isticala svoja dosadašnja postignuća, dok svoj karakter za vrijeme kampanje gotovo da uopće nije isticala. Napad na protivnike kao dominantna strategija korištena je u 10,26 \% objava, što je najmanji postotak među troje kandidata obuhvaćenih analizom.

Tablica 2. Dominantna strategija u objavama Kolinde Grabar-Kitarović

\section{Dominantna strategija u objavama Kolinde Grabar-Kitarović}

Napad na protivnike i/ili stranke koje su ih predložile za kandidate $10,26 \%$ Isticanje domoljublja, podržavanja tradicionalnih vrijednosti, zajedništva i/ili ideologije

$24,36 \%$ 

Isticanje kandidatkinje, njegova/njezina karaktera, vještina ili $14,10 \%$ dosadašnjih postignuća kao glavni razlog glasanja za kandidatkinju Isticanje kandidatkinje kao osobe bliske narodu, okružene građanima Poziv na promjene, isticanje optimizma za budućnost, pobjednički entuzijazam i/ili davanje obećanja za budućnost
Podrška slavnih osoba
Humor ili ironija
Poziv na predizborni skup
Ostalo
UKUPNO

Grabar-Kitarović u 41 \% svojih objava prikazana je kao državnica, dok je u 27 \% objava prikazana kao "jedna od nas". Dodajmo tome da je u 23 \% objava kombinirala prikazivanje sebe kao državnice i kao „jedne od nas“, što nam zapravo govori da je, ukupno gledajući, Grabar-Kitarović u svojoj kampanji na društvenim mrežama u polovici svojih objava nastojala sebe u potpunosti ili djelomično prikazati kao "jednu od nas“.

Državnica

"Jedna od nas"

Kombinacija

Nije moguće odrediti

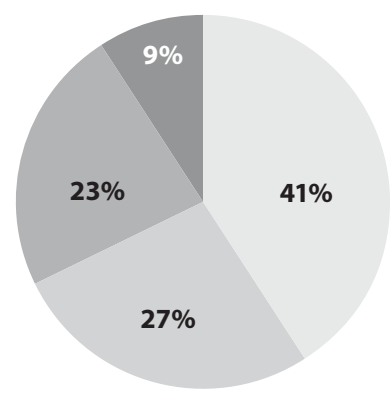

$\Delta$ Graf 2.

Kako je Kolinda Grabar-Kitarović prikazana u objavi?

Tehnika privatizacije kojom se Grabar-Kitarović uvjerljivo najviše služila za vrijeme svoje kampanje, i to u gotovo polovici svojih objava, je prikazivanje sebe u interakciji s građanima (48,72\%), dok je u trećini objava prikazana u neformalnom okruženju $(33,33$ \%). Njezin suprug Jakov Kitarović bio je prisutan u 12,82 \%, a tek u 7,69 \% objava podijelila je neke detalje iz svoga privatnog života, pretežito vezane uz svoje podrijetlo i užu obitelj. Podrška slavnih osoba u njezinim je objavama zastupljena u samo 5,13 \% objava. 
IZVORNI ZNANSTVENI RAD / DOI: 10.20901/ms.12.23.5 / PRIMLJENO: 15.12.2020.

Tablica 3. Tehnike privatizacije u objavama Kolinde Grabar-Kitarović

\begin{tabular}{ll} 
Tehnike privatizacije u objavama Kolinde Grabar-Kitarović & \\
\hline Prisutnost supruge/supruga & $12,82 \%$ \\
Prisutnost poznatih osoba iz svijeta showbusinessa, sporta ili kulture & $5,13 \%$ \\
Kandidatkinja je prikazana u neformalnom, svakodnevnom okruženju & $33,33 \%$ \\
Kandidatkinja je prikazana u interakciji s građanima & $48,72 \%$ \\
Kandidatkinja otkriva informacije iz privatnog života & $7,69 \%$ \\
Referiranje na religiju & $14,10 \%$ \\
UKUPNO & 100 \\
\hline
\end{tabular}

\section{Zoran Milanović}

Kandidat SDP-a Zoran Milanović u analiziranom razdoblju objavio je ukupno 80 objava, a u Grafikonu 3. prikazani su formati tih objava. Njih $60 \%$ objavljeno je u formatu fotografije i teksta. Potom slijede objave u formatu videa i teksta s $24 \%$ te galerija fotografija i teksta s $14 \%$.

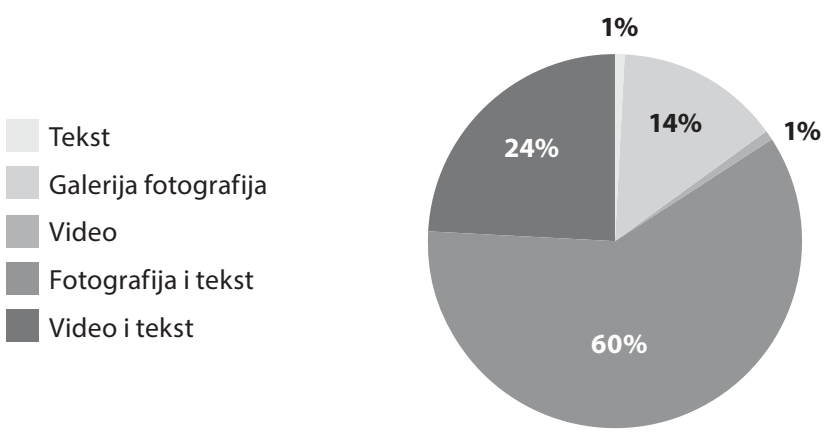

$\Delta$ Graf 3.

Format objava Zorana Milanovića

Milanović je glavni akter u 63,75\% analiziranih objava. Potom slijedi veliki postotak objava u kojima nije bilo moguće odrediti glavnog aktera, u njih čak 22,50\%. Razlog tome je taj što je kandidat u velikoj mjeri objavljivao fotografije s porukama koje nisu sadržavale njegov lik, kao ni pozivnice na predizborne skupove koje čine 15,00 \% svih analiziranih objava. „Obični građanin“ ili građani glavni su akteri u $5 \%$ objava, jednako kao i kombinacija kandidata i predstavnika stranke. Od članova SDP-a, u Milanovićevim objavama pojavIjivali su se članovi Predsjedništva SDP-a Biljana Borzan i Domagoj Hajduković te istaknuti član SDP-a Orsat Miljenić. 
Tablica 4. Glavni akteri u objavama Zorana Milanovića

\begin{tabular}{ll} 
Glavni akteri u objavama Zorana Milanovića & \\
Kandidat & $63,75 \%$ \\
Predstavnik stranke & $/$ \\
Građanin & $5,00 \%$ \\
Predstavnik određene društvene ili interesne skupine & $/$ \\
Slavna osoba & $/$ \\
Član obitelji & $/$ \\
Kandidat + predstavnik stranke & $5,00 \%$ \\
Kandidat + član obitelji (supruga Sanja Musić Milanović) & $3,75 \%$ \\
Nije moguće odrediti & $22,50 \%$ \\
UKUPNO & 100 \\
\hline
\end{tabular}

Najavivši početak svoje kampanje sloganom „predsjednik s karakterom“, bilo je jasno kako će Milanović u središte svoje kampanje staviti upravo svoj osebujni karakter. Isticanje sebe, svog karaktera, vještina ili dosadašnjih postignuća bila je dominantna strategija u $26,25 \%$ objava. U $25 \%$ objava kao dominantnu strategiju koristio je poziv na promjene, isticanje optimizma za budućnost, pobjednički entuzijazam i/ili davanje obećanja za budućnost. Svoje protivnike i/ili stranke koje su ih predložile za kandidate često je u svojim objavama napadao, a time se kao dominantnom strategijom služio u $20 \%$ svojih objava. Na Miroslava Škoru neizravno se referirao u samo tri objave, a glavne mete njegovih napada u najvećoj su mjeri bile Grabar-Kitarović i stranka HDZ. Tablica 5. prikazuje strategije kojima se Milanović koristio u svojoj kampanji.

Tablica 5. Dominantna strategija u objavama Zorana Milanovića

\section{Dominantna strategija u objavama Zorana Milanovića}

Napad na protivnike i/ili stranke koje su ih predložile za kandidate

$20,00 \%$

Isticanje domoljublja, podržavanja tradicionalnih vrijednosti,

$5,00 \%$

zajedništva i/ili ideologije

Isticanje kandidata, njegova/njezina karaktera, vještina ili

$26,25 \%$

dosadašnjih postignuća kao glavni razlog glasovanja za tog kandidata

Isticanje kandidata kao osobu blisku narodu, okruženu građanima

$6,25 \%$

Poziv na promjene, isticanje optimizma za budućnost,

$25,00 \%$

pobjednički entuzijazam i/ili davanje obećanja za budućnost

Podrška slavnih osoba

/

Humor ili ironija

/

Poziv na predizborni skup

$15,00 \%$

Ostalo

$2,50 \%$

UKUPNO

100 
U više od pola svojih objava Milanović je prikazan kao državnik (51\%). Kao „jedan od nas" nastojao se prikazati u $14 \%$ objava, dok je u $10 \%$ objava kombinirao prikazivanje sebe kao državnika i običnog građanina. Za $25 \%$ objava nije bilo moguće odrediti kako je kandidat prikazan, budući da njegova lika u objavi nije bilo.

Državnik
"Jedan od nas"
Kombinacija
Nije moguće odrediti

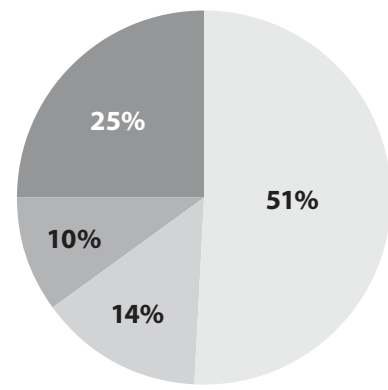

Graf 4.

Kako je Zoran Milanović prikazan u objavi?

Baš kao i u slučaju njegove protukandidatkinje Grabar-Kitarović, prikazivanje u interakciji s građanima bila je tehnika privatizacije političara kojom se Milanović najčešće koristio u svojim objavama, u 16,25 \% analiziranih objava. U nešto manjem postotku, u $15 \%$ objava, Milanović je prikazan u neformalnom okruženju. Milanovićeva supruga Sanja pojavljuje se u $10 \%$ objava, a u samo 6,25 \% objava Milanović je dijelio informacije iz svoga privatnog života, koje se pretežito odnose na njegovu obitelj i razdoblje koje je proveo izvan politike. $U$ analiziranom razdoblju Milanovićeve kampanje nije zabilježena nijedna objava na kojoj su prisutne slavne osobe iz svijeta showbusinessa, sporta ili kulture.

Tablica 6. Tehnike privatizacije u objavama Zorana Milanovića

\begin{tabular}{ll} 
Tehnike privatizacije u objavama Zorana Milanovića & \\
\hline Prisutnost supruge/supruga & $10,00 \%$ \\
Prisutnost poznatih osoba iz svijeta showbusinessa, sporta ili kulture & $/$ \\
Kandidat je prikazan u neformalnom, svakodnevnom okruženju & $15,00 \%$ \\
Kandidat je prikazan u interakciji s građanima & $16,25 \%$ \\
Kandidat otkriva informacije iz privatnog života & $6,25 \%$ \\
Referiranje na religiju & $2,50 \%$ \\
UKUPNO & 100 \\
\hline
\end{tabular}




\section{Miroslav Škoro}

Miroslav Škoro predsjednički je kandidat koji je u svojoj kampanji objavio najviše objava, njih 85 . Objave u formatu videa i teksta dominirale su u njegovoj kampanji s $38 \%$, dok su u $35 \%$ slučajeva objave bile u formatu fotografije i teksta.

Tekst

Fotografija

Video

Fotografija i tekst

Galerija fotografija i tekst

Video i tekst

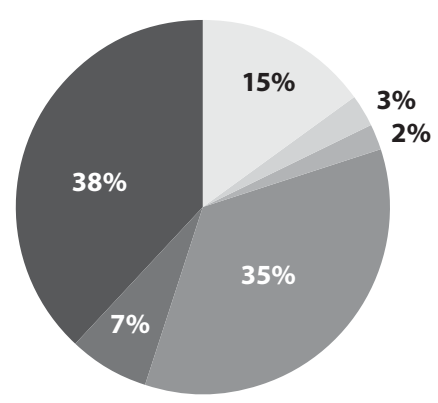

$\Delta$ Graf5.

Format objava Miroslava Škore

Škoro je glavni akter u 69,41 \% svojih objava. Kao i u slučaju Zorana Milanovića, u gotovo istom postotku, u 22,35\% Škorinih objava nije bilo moguće odrediti glavnog aktera u objavi zbog velikog broja objava u formi teksta ( $15 \%$ ) te zbog fotografija s porukom koje nisu sadržavale Škorin lik. Zatim s istim postotkom od 3,53 \% slijede građani kao glavni akteri objave te kombinacija kandidata i slavne osobe, među kojima su pjevači Jacques Houdek, Tiho Orlić i Marko Pecotić te glumac Vedran Mlikota.

\section{Tablica 7. Glavni akter u objavama Miroslava Škore}

\begin{tabular}{ll} 
Glavni akter u objavama Miroslava Škore & \\
Kandidat & $69,41 \%$ \\
Predstavnik stranke & $/$ \\
Građanin & $3,53 \%$ \\
Predstavnik određene društvene ili interesne skupine & $/$ \\
Slavna osoba & $/$ \\
Član obitelji & $1,18 \%$ \\
Kandidat + član obitelji & $3,53 \%$ \\
Kandidat + slavna osoba & $22,35 \%$ \\
Nije moguće odrediti & 100 \\
TOTAL & \\
\hline
\end{tabular}


Poziv na promjene, isticanje optimizma za budućnost, pobjednički entuzijazam i/ili davanje obećanja za budućnost dominantna je strategija u 36,47 \% Škorinih objava. Uspoređujući s protukandidatima, Škoro je na svom Facebooku najčešće kao dominantnu strategiju koristio napad na svoje protivnike, odnosno stranke koje ih podržavaju (21,18 \%).

Isticanje domoljublja, podržavanja tradicionalnih vrijednosti, zajedništva i/ili ideologije bila je dominantna strategija u 12,94 \% Škorinih objava, dok je isticanje sebe, svog karaktera, vještina ili dosadašnjih postignuća kao dominantnu strategiju koristio u 7,06 \% objava. Pretežito je isticao svoje poduzetničko radno iskustvo i sebe kao nezavisnoga kandidata.

U jednakom postotku, kao jedini među kandidatima obuhvaćenim ovom analizom, koristio je humor kao dominantnu strategiju objave. Posebice se koristio tom taktikom u vrijeme predizborne šutnje, koju je kršio kada je tijekom 21. i 22. prosinca objavio četiri objave u formatu fotografije i teksta, u kojima je na humorističan način pozivao građane da izađu na birališta.

Tablica 8. Dominantna strategija u objavama Miroslava Škore

\begin{tabular}{|c|c|}
\hline \multicolumn{2}{|l|}{ Dominantna strategija u objavama Miroslava Škore } \\
\hline Napad na protivnike i/ili stranke koje su ih predložile za kandidate & $21,18 \%$ \\
\hline $\begin{array}{l}\text { Isticanje domoljublja, podržavanja tradicionalnih vrijednosti, } \\
\text { zajedništva i/ili ideologije }\end{array}$ & $12,94 \%$ \\
\hline $\begin{array}{l}\text { Isticanje kandidata, njegova/njezina karaktera, vještina ili dosadašnjih } \\
\text { postignuća kao glavni razlog glasovanja za tog kandidata }\end{array}$ & $7,06 \%$ \\
\hline Isticanje kandidata kao osobu blisku narodu, antielitista & $2,35 \%$ \\
\hline $\begin{array}{l}\text { Poziv na promjene, isticanje optimizma za budućnost, } \\
\text { pobjednički entuzijazam i/ili davanje obećanja za budućnost }\end{array}$ & $36,47 \%$ \\
\hline Podrška slavnih osoba & / \\
\hline Humor ili ironija & $7,06 \%$ \\
\hline Poziv na predizborni skup & $5,88 \%$ \\
\hline Ostalo & / \\
\hline TOTAL & 100 \\
\hline
\end{tabular}

Iznenađujuće, Škoro je od svih analiziranih kandidata u najvećem postotku objava prikazan kao državnik (62 \%). Najmanje se prikazivao kao jedan od nas, u 7 \% objava, a tek u $5 \%$ objava kombinirao je prikazivanje sebe kao državnika i „jednog od nas“. Jedan od mogućih razloga koji bi objasnio takve podatke jest taj što je Škoro osoba koja dolazi iz svijeta showbusinessa i koja je, naspram svojih protukandidata, politički neiskusna. Škoro, kao pjevač po zanimanju, u svojoj kampanji naprosto nije imao potrebu sebe dodatno „humanizirati“, već mu je glavni zadatak bio da sebe predstavi kao ozbiljnog političara te da se makne od imidža estradnog pjevača. 
Državnik

"Jedan od nas"

Kombinacija

Nije moguće odrediti

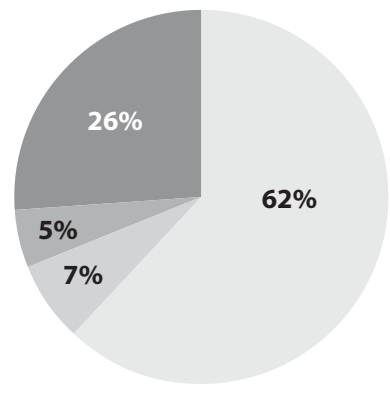

A Graf6.

Kako je Miroslav Škoro prikazan u objavama?

Referiranje na religiju najčešća je tehnika privatizacije kojom se Škoro koristio, u 18,82 $\%$ svojih objava. Najmanje od kandidata prikazivao se u neformalnom okruženju $(11,77 \%)$ i u interakciji s građanima (10,59\%), a više od drugih protukandidata dijelio je informacije iz privatnog života, koje se uglavnom odnose na njegovo podrijetlo i privatni posao $(9,41$ $\%)$ objava. U istom postotku u njegovim objavama bile su prisutne poznate osobe iz svijeta showbusinessa, sporta ili kulture.

Tablica 9. Tehnike privatizacije u objavama Miroslava Škore

\begin{tabular}{ll} 
Tehnike privatizacije u objavama Miroslava Škore & \\
\hline Prisutnost supruge/supruga & $4,71 \%$ \\
Prisutnost poznatih osoba iz svijeta showbusinessa, sporta ili kulture & $9,41 \%$ \\
Kandidat je prikazan u neformalnom, svakodnevnom okruženju & $11,77 \%$ \\
Kandidat je prikazan u interakciji s građanima & $10,59 \%$ \\
Kandidat otkriva informacije iz privatnog života & $9,41 \%$ \\
Referiranje na religiju & $18,82 \%$ \\
UKUPNO & 100 \\
\hline
\end{tabular}

\section{ZAKLJUČAK}

Rezultati istraživanja pokazali su da su kandidati na hrvatskim predsjedničkim izborima 2019./2020. u značajnoj mjeri koristili Facebook za privatizaciju, odnosno personalizaciju politike. Koristili su različite tehnike i u različitoj mjeri, ali s istim ciljem - kako bi se približili biračima i djelovali im kao "jedni od nas".

Grabar-Kitarović u analiziranom razdoblju objavila je 78 objava, od kojih je najveći broj bio u formatu fotografije i teksta te galerije fotografija i teksta. Uspoređujući je s protu- 
kandidatima, objavila je najviše fotografija, ali i najmanje objava u videoformatu. U gotovo 75 posto objava Grabar-Kitarović je glavni akter objave, što potvrđuje da je vodila personaliziranu političku kampanju. U značajnom dijelu objava uz sebe je imala i predstavnike Hrvatske demokratske zajednice iz čega proizlazi da joj je jedan od ciljeva u kampanji na Facebooku bio zadržavanje naklonost birača te političke stranke. Tome u prilog ide i podatak da je najčešća dominantna strategija u njezinim objavama bila isticanje domoljublja, podržavanje tradicionalnih vrijednosti, zajedništva i/ili ideologije. Usto, isticala je pobjednički entuzijazam i davala obećanja za budućnost, prikazivala se kao osoba bliska narodu i pozivala birače na predizborne skupove. Svoje vrline i karakter u objavama nije isticala te je samim time propustila priliku da se istakne među ostalim kandidatima. Grabar-Kitarović najmanje se kao dominantnom strategijom služila napadima na protukandidate. Fokus njezine kampanje bio je usmjeren na to da se prikaže kao kandidatkinja bliska narodu, što potvrđuje i podatak da je u polovini svojih objava u potpunosti ili djelomično prikazana kao „jedna od nas“. Pritom se najčešće služila tehnikom prikazivanja u interakciji s građanima i prikazivanjem u neformalnom okruženju. U svojim objavama uspješno je "humanizirala" svoj imidž i ostavila dojam „žene iz naroda“.

Milanović je u analiziranom razdoblju objavio 80 objava koje su najčešće bile u formatu fotografije i teksta te videa i teksta. U 63,75\% objava Milanović je glavni akter, a najčešće se kao dominantnom strategijom koristio isticanjem sebe, svog karaktera, vještina ili dosadašnjih postignuća. Pored toga, pozivao je na promjene te žestoko napadao protukandidatkinju Grabar-Kitarović i stranku HDZ. Svoj osebujni karakter i komunikacijski stil, koji je javnost imala priliku upoznati dok je obnašao funkciju predsjednika Vlade, stavio je u središte kampanje i javnosti se predstavio kao autentičan kandidat koji ima čvrst stav. Sarkastično-podcjenjivačku komunikaciju o kojoj piše Grbeša-Zenzerović (2014) uspio je obuzdati te je u vrijeme ove kampanje nastojao "humanizirati“ svoj imidž. U većini objava prikazivao se kao državnik, no također se i u značajnom postotku objava prikazivao u neformalnom okruženju, u interakciji s građanima ili u društvu supruge. Iskoristio je potencijal društvenih mreža da istakne svoju osobnost i stvori osobni brend te je naposljetku pobijedio u drugom krugu predsjedničkih izbora.

Škoro je objavio najviše objava, njih 87, od čega je najveći dio objava bio u formatu videa i teksta, a zatim i fotografija i teksta. U gotovo 70 posto objava Škoro je glavni akter, a u svojim objavama najčešće je pozivao na promjene, isticao optimizam za budućnost, pobjednički entuzijazam i/ili davao obećanja za budućnost. U usporedbi s protukandidatima, na svom je Facebooku najčešće kao dominantnu strategiju koristio napad na svoje protivnike, odnosno stranke koje ih podržavaju. Taj podatak ne iznenađuje, budući da je Škoro populist koji je čitavu svoju kampanju temeljio na napadima na vladajuće elite. Sebe je predstavljao kao "predsjednika iz naroda“, no istodobno se najmanje u kampanji na Facebooku prikazivao kao „jedan od nas“. Za razliku od protukandidata, u puno manjoj mjeri je sebe prikazivao u interakciji s ljudima ili u neformalnom okruženju. Mogući razlog tome leži u činjenici da je Škoro osoba koja dolazi iz svijeta showbusinessa i koja je do kandidature za predsjednika Republike imala tek nekoliko mjeseci iskustva u aktivnoj politici. Njemu je u ovoj kampanji veći izazov predstavljalo da sebe afirmira kao ozbiljnog političara i državnika nego kao osobu iz naroda. Ostavlja se otvoreno pitanje bi li Škoro osvojio 
više glasova u prvom krugu da se u većoj mjeri služio tehnikama privatizacije politike. Kao i Grabar-Kitarović, nije isticao svoje privatne osobine i karakter. Unatoč tome što nije ušao u drugi krug, ostvario je značajan uspjeh i time se pozicionirao na hrvatskoj političkoj sceni. Uspoređujući s prethodnim istraživanjima privatizacije na društvenim mrežama u Hrvatskoj, ovo istraživanje pokazalo je da su se kandidati u velikoj mjeri služili tehnikama privatizacije politike. Pobjedu na izborima odnio je „predsjednik s karakterom “ koji se uspješno istaknuo među ostalim kandidatima, naglašavajući svoje privatne osobine i dosadašnja postignuća. Daljnja istraživanja fenomena privatizacije politike u Hrvatskoj mogla bi ponuditi odgovor na pitanje je li značajno korištenje tehnika privatizacije politike na predsjedničkim izborima dio trenda koji će se nastaviti te kako korištenje komunikacijske strategije u čijem su središtu osebujni karakter i privatne osobine kandidata utječu na rezultate izbora.

\section{LITERATURA}

>Bago, M. (2019a, 6. prosinca). EKSKLUZIVNO Veliko iznenađenje u rejtingu: Grabar-Kitarović, Milanović i Škoro unutar statističke pogreške. Dnevnik.hr. Preuzeto 14.5.2020., s https://dnevnik.hr/vijesti/ predsjednicki-izbori/dnevnik-nove-tv-donosi-prvo-istrazivanje-rejtinga-svih-11-sluzbenihpredsjednickih-kandidata-ima-i-iznenadjenja---586031.html

>Bago, M. (2019b, 20. prosinca). EKSKLUZIVNO Posljednje istraživanje uoči izborne šutnje: Milanović $i$ Grabar-Kitarović vode mrtvu utrku, Škoro zaostaje. Dnevnik.hr. Preuzeto 14.5.2020., s https://dnevnik. $\mathrm{hr} / \mathrm{vijesti/predsjednicki-izbori/ekskluzivno-veliko-istrazivanje-rejtinga-kandidata-uoci-prvog-}$ kruga-predsjednickih-izbora---587846.html

>Dalton, R. J. (2003). Political Cleavages, Issues and Electoral Change. U L. Le Duc, L. Niemi i P. Norris (ur.), Comparing Democracies 2. (str. 319-342). Thousand Oaks: Sage Publications. https://doi. org/10.1017/S1755773910000366

>Dalton, R. J. i Wattenberg, M. P. (2000). Parties without partisans: political change in advanced industrial democracies. Oxford: Oxford University Press. https://doi.org/ 10.1093/0199253099.001.0001

>Dnevnik.hr. (2019a, 30. studenog). Predsjednica putem Facebooka poručila građanima: "Vi ste moja Hrvatska za koju se borim i kojoj sam odgovorna. Ovo su izbori o Hrvatskoj". Preuzeto 14.5.2020., s https://dnevnik.hr/vijesti/predsjednicki-izbori/kolinda-grabar-kitarovic-na-facebooku-ovo-nisuizbori-o-jednoj-osobi-ovo-su-izbori-o-hrvatskoj-i-za-nasu-jedinu-i-vjecnu-hrvatsku---585197.html >Dnevnik.hr. (2019b, 26. studenog). Štrajk uzeo danak: HDZ-u pada potpora, pada i SDP-u, ali iz drugog razloga. Jedan političar je dobitnik mjeseca. Preuzeto 14.5.2020, s https://dnevnik.hr/vijesti/ hrvatska/crobarometar-hdz-u-i-sdp-u-topi-se-potpora-ali-zbog-razlicitih-razloga-samo-jedanpoliticar-je-dobitnik---584659.html >Državno izborno povjerenstvo Republike Hrvatske. (2011, prosinac). Izbori za zastupnike u Hrvatski sabor. Preuzeto 14.7.2020., s https://www.izbori.hr/arhiva-izbora/index.html\#/app/parlament-2011 >Državno izborno povjerenstvo Republike Hrvatske. (2014, prosinac). Izbori za predsjednika Republike Hrvatske. Preuzeto 13. srpnja 2020., s https://www.izbori.hr/arhiva-izbora/index.html\#/ app/predsjednik-2014.

>Državno izborno povjerenstvo Republike Hrvatske. (2020, siječanj). Izbori za predsjednika Republike Hrvatske. Preuzeto 14.7.2020., s https://www.izbori.hr/arhiva-izbora/index.html\#/app/ predsjednik-2019

>Forbes.com. (2019, 12. prosinca). \#47 Kolinda Grabar-Kitarovic. Preuzeto 13.7.2020., s https://www. forbes.com/profile/kolinda-grabar-kitarovic/\#7c1a44913843

$>$ Grbeša, M. (2004). Personalization in presidential elections in Croatia in 2000: How personal did the candidates go and what did the press cover? Politička misao, 41(5), 52-73. 
$>$ Grbeša, M. (2008). Personality politics in Croatia: An inquiry into election campaigns, media coverage and public perception in the 2003 and 2007 parliamentary elections. Ljubljana: Fakultet društvenih znanosti.

$>$ Grbeša, M. (2010). Privatisation of Politics in Croatia: Analysis of the 2003 and 2007 Parliamentary Elections. Medijska istraživanja, 16(2), 57-78.

$>$ Grbeša-Zenzerović, M. (2014). Je li za loš imidž Milanovićeve vlade kriv Kennedy? Političke analize, 5(20), 39-44.

>Henjak, A. (2019). Što nam predsjednički izbori mogu reći o političkim trendovima u Hrvatskoj. Revija za sociologiju, 49(3), 419-428.

>Holz-Bacha, C. (2004). Germany: How the Private Life of Politicians Got into the Media.

Parliamentary Affairs, 57(1), 41-52. https://doi.org/10.1093/pa/gsh004

>Holtz-Bacha, C., Langer, A. I. i Merkle, S. (2014). The personalisation of politics in comparative perspective: campaign coverage in Germany and the United Kingdom. European Journal of Communication, 29(2), 153-170 https://doi.org/10.1177/0267323113516727

>Hr.n1info.com. (2019, 20. prosinca). "Milanovićeva je retorika kao moćni Mercedes, a predsjedničina kao polovni Golf". Preuzeto 15.7.2020., s https://hr.n1info.com/vijesti/a469719andquotmilanoviceva-je-retorika-kao-mocni-mercedes-a-predsjednicina-kao-polovnigolfandquot/ >Internetworldstats.com. (2020, prosinac). Internet Usage in the European Union. Preuzeto 16.7.2020., s https://www.internetworldstats.com/stats9.htm.

>Karvonen, L. (2009). The Personalisation of Politics: A Study of Parliamentary Democracies.

Colchester: ECPR Press. https://doi.org/10.1080/10361146.2012.704891

>Langer, A. I. (2010). The Politicization of Private Persona: Exceptional Leaders or the New Rule? The Case of the UK and the Blair Effect. The International Journal of Press/Politics, 15(1), 60-76. https://doi. org/10.1177/1940161209351003

>Langer, A. I. (2006). The politicisation of private persona: the case of Tony Blair in historical perspective. Doktorska disertacija.

>Lipset, S. M. i Rokkan, S. (1967). Party Systems and Voter Alignments, Cross-National Perspectives, $1-64$.

>Mahmutović, D. (2019, 17. lipnja). Milanović 2014.: Nisam i nikad neću biti

predsjednik Hrvatske. 24sata.hr. Preuzeto 14.5.2020., s https://www.24sata.hr/news/

milanovic-2014-nisam-i-nikad-necu-biti-predsjednik-hrvatske-635014

$>$ Mughan, A. (2000). Media and the Presidentialization of Parliamentary Elections. London: Palgrave. https://doi.org/10.1057/9781403920126

>Opačak Klobučar, T. (2014, 9. prosinca). S kampanjom krenula točno u ponoć: 'Ja sam Kolinda, žena iz naroda, bit ću predsjednica'. Večernji.hr. Preuzeto 12.7.2020., s https://www.vecernji.hr/vijesti/ kampanju-pocela-tocno-u-ponoc-ja-sam-kolinda-zena-iz-naroda-bit-cu-vasa-predsjednica-978101 >Puljić-Šego, I. (2015, 7. siječnja). Euforičan skup HDZ-a u Domu sportova: 'Dosta je bilo Zorana Milanovića i lve Josipovića'. Večernji.hr. Preuzeto 15.7.2020., s https://www.vecernji.hr/vijesti/ euforican-skup-hdz-a-u-domu-sportova-dosta-je-bilo-zorana-milanovica-i-ive-josipovica-982956 $>$ Raos, V. (2015). Prijelomi i trendovi: predsjednički izbori u Hrvatskoj. Političke analize, 6(21), 33-38. $>$ Sinčić Ćorić, D., Brečić, R. i Šimunjak, M. (2017). Reaching, Engaging and Bonding with Voters on Social Media: The Case of 2014/2015 Croatian Presidential Elections. Medijske studije, 8(16), 61-76. https://doi.org/10.20901/ms.8.16.5

>Stanyer, J. i Wring, D. (2004). Public images, private lives: an introduction, Parliamentary Affairs, 57(1), 1-8. https://doi.org/10.1093/pa/gsh001

$>$ Street, J. (2004). Celebrity Politicians: Popular Culture and Political Representation.

The British Journal of Politics \& International Relations, 6, 432-452. https://doi. org/10.1111/j.1467-856X.2004.00149.x

$>$ Swanson, D. i Mancini, P. (1996). Politics, Media and Modern Democracy. Westport: Praeger Series. >Šalaj, B. (2012). Što je populizam? Političke analize, 3(11), 55-61. 
IZVORNI ZNANSTVENI RAD / DOI: 10.20901/ms.12.23.5 / PRIMLJENO: 15.12.2020.

>Šimunjak, M., Sinčić Ćorić, D. i Brečić, R. (2017). Political Impression Management Through Direct and Mediated Communication: The 2014/2015 Croatian Presidential Elections. Društvena istraživanja, 26(4), 539-560. https://doi.org/10.5559/di.26.4.05

$>$ Šimunjak, M. (2012) Privatni život kao dio komunikacijske strategije hrvatskih političara:

Predsjednički izbori 2009./2010. Medijske studije, 3(5), 34-49.

$>$ Van Aelst, P., Sheafter, T. i Stanyer, J. (2011). The Personalization of Mediated Political Communication: A Review of Concepts, Operationalizations and Key Findings. Journalism, 13(2), 203-220. 


\title{
POLITICAL COMMUNICATION OF THE CANDIDATES ON SOCIAL NETWORKS IN 2019-2020 CROATIAN PRESIDENTIAL ELECTION
}

\section{Gabriela Galić :: Domagoj Bebić}

\begin{abstract}
The rise of "candidate-centered politics" has influenced a change in communication strategies of politicians who are increasingly using privatisation techniques to get closer to their voters. Social media have proven to be an ideal channel for "softening" their images. The aim of this paper is to investigate whether, and to what extent, the candidates used social media for privatization, i.e., personalization of politics, in the 2019-2020 Croatian presidential election. Using the content analysis method, researchers discovered that the candidates significantly used privatization techniques on social media to present themselves as "one of us". The winner of the election was Zoran Milanović, who led a completely personalized campaign in which he emphasized rather frequently his distinctive character and his personal characteristics.
\end{abstract}

\section{KEY WORDS}

CROATIA, PRESIDENTIAL ELECTIONS, FACEBOOK, PRIVATISATION OF POLITICS

Authors'note

Gabriela Galić :: gabriela.galic01@gmail.com

Domagoj Bebić :: Faculty of Political Science, University of Zagreb :: domagoj@edemokracija.hr 